DZIEJE NAJNOWSZE, ROCZNIK XLVII - 2015, 1

PL ISSN 0419-8824

Piotr Abryszeński

Gdańsk

\title{
Stanowisko duchownych Pomorza Gdańskiego wobec Grudnia 1970 w świetle dokumentów SB. Próba charakterystyki
}

Kościół katolicki po drugiej wojnie światowej spełniał rolę faktycznego rzecznika społeczeństwa polskiego, był wyrazicielem jego potrzeb i dążeń. Dla komunistów już w pierwszych latach po wojnie stał się przeszkodą w całkowitym zniewoleniu narodu, stanowiąc dla niego oparcie $\mathrm{i}$ - po rozbiciu podziemia niepodległościowego — tworząc podstawy do tworzenia przyszłej opozycji demokratycznej. Zdecydowana postawa duchowieństwa, które w jednoznaczny sposób opowiedziałoby się za postulatami stawianymi przez demonstrantów w czasie wydarzeń Grudnia 1970 r. i które zachęcałoby do masowego udziału w protestach czy walkach ulicznych, zapewne wpisałaby się w swoistą mitologię narodową — tym bliższą romantyzmowi, im odleglejszą czasom nam współczesnym. Tymczasem gdańscy kapłani w omawianym okresie zachowali się dość powściągliwie ${ }^{1}$.

Na wieść o wybuchu strajku w Stoczni Gdańskiej im. Lenina 14 XII 1970 r. działacze partyjni z Komitetu Wojewódzkiego nie zamierzali zwlekać z interwencją w kurii biskupiej.

\footnotetext{
${ }^{1}$ Wśród opracowań dotyczących postawy Kościoła należałoby wymienić w kolejności chronologicznej: W. Turek, Kościół wobec wydarzeń Grudnia '70 w Gdańsku, w: Grudzień przed Sierpniem. WXXV rocznicę wydarzeń grudniowych, red. L. Mażewski, W. Turek, Gdańsk 1996; J. Eisler, , Kler nie zaostrza sytuacji”. Grudzień 1970 w dokumentach Departamentu IV MSW, „Więź” 2001, nr 7; J. Mazur, Kościót wobec wydarzeń Grudnia 1970 i Sierpnia 1980, w: Grudzień 1970 geneza Sierpnia 1980, red. K. Kozłowski, Szczecin 2000; J. Eisler, J. Żaryn, Grudzień 1970 roku w oczach Episkopatu Polski, „Polska 1944/45-1989. Studia i Materiały” 2006, t. VII (artykuł ten został przedrukowany w: J. Żaryn, Kościót - Człowiek - Naród, czyli opowieść optymistyczna o Polakach w XX wieku, Warszawa 2012); Z. Stanuch, Duchowieństwo katolickie województwa szczecińskiego wobec protestów z grudnia 1970 i stycznia 1971 r., w: „Intelektualiści polscy milcza zupetnie”. Grudzień 1970-styczeń 1971 w Szczecinie, red. S. Ligarski, Szczecin 2010; i ostatnio P. Abryszeński, Normalizacja stosunków z Kościołem katolickim jako próba odbudowy społecznego zaufania przez władze komunistyczne w pierwszych miesiącach po Grudniu '70, w: Poczucie bezpieczeństwa Polaków w dekadzie gierkowskiej. Bezsilność i zmęczenie. Antropologia codzienności w latach 70., red. J. Farysej, H. Lisiak, K. Siemaszko, Poznań 2014. Stosunki między władzą komunistyczną a Kościołem katolickim charakteryzowali też A. Friszke, PRL wobec Kościoła. Akta Urzędu do Spraw Wyznań 1970-1978, Warszawa 2010, czy J. Eisler, Grudzień 1970. Geneza, przebieg, konsekwencje, Warszawa 2012.
} 
Przedstawiciele władzy pojawiali się tam jedynie w nadzwyczajnych sytuacjach, co musiało dać do myślenia biskupowi gdańskiemu Edmundowi Nowickiemu. Z polecenia przewodniczącego Prezydium Wojewódzkiej Rady Narodowej Tadeusza Bejma na rozmowę z nim wysłany został zastępca kierownika Wydziału do Spraw Wyznań Józef Mazur. Spotkanie rozpoczęło się o szesnastej. Biskup Nowicki nie miał jeszcze żadnych informacji na temat demonstracji robotników, toteż Mazur wykorzystał szansę, by w odpowiedni sposób je przedstawić. Nie można wykluczać, że jego początkowa reakcja zaważyła na percepcji całego przebiegu wydarzeń na Wybrzeżu i w konsekwencji spowodowała daleko idącą powściągliwość gdańskiej kurii. W rozmowie z Mazurem biskup miał potępić ,awantury” w Gdańsku². Trudno ocenić, czy rzeczywiście padło z jego ust takie określenie. Zastępca kierownika WdSW nie mógł jeszcze wiedzieć o jakichkolwiek walkach w mieście, gdyż do pierwszej konfrontacji doszło w okolicach wiaduktu Błędnik niemal dokładnie w tym samym czasie, kiedy rozpoczynało się spotkanie w kurii. A dotąd przebieg manifestacji był niezwykle spokojny. Takie uzasadnienie brzmi niezwykle atrakcyjnie, ale wydaje się mało prawdopodobne, by wysłannik WdSW wiedział o planowanej przez władze prowokacji wobec strajkujących robotników i zaostrzeniu spokojnego dotychczas protestu. Możliwe, że sporządzając wieczorną notatkę z rozmowy, bogatszy o informacje na temat zajść w mieście, na własne potrzeby nieco ubarwił reakcję hierarchy. Jednak cel spotkania Mazura z biskupem gdańskim był jasny — wymusić na kurii potępienie demonstracji.

Inną kwestią, jaką Józef Mazur poruszył na rozmowie z biskupem Edmundem Nowickim, stanowił rzekomy udział kilku duchownych w tłumie manifestantów. Na wieść o tym biskup wyraził żal, że nie otrzymał listy ich nazwisk ${ }^{3}$. Kwestia ta nie znajduje jednak potwierdzenia w zachowanych dokumentach. Faktem jest, że bardzo szybko zaczęła krążyć w formie plotki - co ciekawe, padła na przedświątecznym spotkaniu biskupa z duchowieństwem diecezjalnym i zakonnym, które odbyło się w gdańskim seminarium duchownym 22 XII $1970 \mathrm{r}$. Publicznie biskup ostro skrytykował użycie siły przeciwko demonstrantom dopiero podczas pasterki, mówiąc: „na naszych oczach została dokonana zbrodnia kainowa"4 . Z treści sprawozdania wynika, że słowa te padły w czasie homilii. Warto podkreślić, że sformułowanie to nie znalazło się w tekście kazania wydrukowanego na łamach „Miesięcznika Diecezjalnego Gdańskiego" ze stycznia-lutego $1971 \mathrm{r}^{5}$

14 grudnia po pierwszych starciach demonstrantów z milicją, gdańska bezpieka odnotowała żywe zainteresowanie przebiegiem wydarzeń wśród księży zarówno w Trójmieście, jak i poza nim. Zastanawiali się oni, kogo tym razem oficjalnie uzna się za „rozrabiaczy”, skoro „syjonistów” już nie ma ${ }^{6}$. Dopiero 17 grudnia kuria biskupia w Gdańsku wydała specjalne zarządzenie w sprawie odmówienia we wszystkich kościołach i na wszystkich mszach na terenie całego miasta specjalnej modlitwy. Miało to nastąpić następnego dnia, w niedzielę, w miejsce modlitwy powszechnej w związku z wydarzeniami z 14-16 grudnia w mieście. Następnie celebrans miał zaintonować antyfonę Pod Twoja obronę ${ }^{7}$ Ogłoszenie dokumentu,

\footnotetext{
2 Archiwum Instytutu Pamięci Narodowej w Gdańsku (AIPN Gd), 299/141, Notatka służbowa, 14 XII 1970, k. 392.

${ }^{3}$ Ibidem.

${ }^{4}$ AIPN Gd, 003/169, t. I, Sprawozdanie z przebiegu akcji „Jesień 70” na terenie województwa gdańskiego, 3 I 1971, k. 28.

${ }_{5}^{5}$ Kazanie ks. biskupa gdańskiego w noc Bożego Narodzenia 1970 podczas Mszy św. w katedrze oliwskiej (fragmenty), „Miesięcznik Diecezjalny Gdański” 1971, r. 15, s. 28-30.

${ }^{6}$ AIPN Gd, 003/14, t. II, Meldunek sytuacyjny na godz. 18.30, k. 13.

${ }^{7}$ AIPN Gd, 0046/225, t. III, Informacja [na temat sytuacji w Kościele rzymskokatolickim], k. 89; ibidem, Odpis kurendy nr 75/1970, k. 90. Tam też tekst modlitwy: „W związku z wydarzeniami ostatnich
} 
jak można przypuszczać, było powiązane ze stopniowym normalizowaniem się sytuacji na ulicach Gdańska. Nie było oczywiście odpowiedzią na masakrę w Gdyni, o której kuria nie mogła być poinformowana w momencie przygotowywania tekstu kurendy. W jednym $\mathrm{z}$ meldunków SB zawarta jest informacja, że w kilku kościołach wierni odśpiewali również pieśń Boże, coś Polskę. Część kapłanów przyłączała się w kazaniach do apelu o spokój, o zachowanie dystansu wobec krążących po mieście plotek ${ }^{8}$.

Po telefonicznym zaproszeniu Tadeusza Bejma we wtorek 22 grudnia doszło do pierwszego po rewolcie grudniowej spotkania w PWRN z biskupem Edmundem Nowickim, któremu towarzyszył ks. Jan Majder. Podjęto wówczas temat nocnych pochówków — Bejm zapewniał, że wszyscy zabici zostali pochowani z zachowaniem obrzędu pogrzebowego oraz w obecności rodzin i kapłanów. Na żądanie wycofania się z odczytywania listu Episkopatu Polski odnoszącego się do sytuacji demograficznej w kraju biskup stwierdził krótko, że dowiedział się o nim przed kilkoma dniami i jeszcze nie zdążył z nikim tej kwestii przedyskutować. Korzystając z okazji, wysunął powtarzany od lat postulat budownictwa sakralnego w Gdańsku — rozpatrzenie tych spraw zostało jednak przełożone na następny miesiąc. Wszyscy obecni zgodzili się co do tego, że „nieprzyjazne Polsce siły” dążą do dyskredytacji podpisanego przed kilkoma dniami układu z RFN. Biskupa Nowickiego interesowała ponadto kwestia zniesienia godziny milicyjnej ze względu na zbliżające się święta Bożego Narodzenia oraz konieczność odprawienia pasterki. Najwyraźniej uspokoiło go zapewnienie, że odpowiednie organy zostały o tym fakcie poinformowane i księża mogą bez przeszkód przygotowywać się do świąt ${ }^{9}$.

Pewien dystans zachowywał także biskup pomocniczy diecezji chełmińskiej Zygfryd Kowalski, który w nawet prywatnych rozmowach powoływał się na informacje, jakie podawała telewizja. W oficjalnej wersji wydarzeń akcentowano ogrom szkód, liczne kradzieże i zniszczenia sklepów, podkreślano, że w czasie zajść 150 milicjantów odniosło obrażenia. To wszystko musiało silnie wpłynąć na postrzeganie przez biskupa protestu grudniowego. Dodawał on jednak, że „chyba nie wszystko i nie wszędzie będzie się o tym mówić i pisać. Są to rzeczy przykre i tragiczne zarazem" ". Wg oceny naczelnika Wydziału IV Aleksandra Świerczyńskiego biskup Kowalski nie mówił wprost, choć zachowywał się w taki sposób, „aby dać do zrozumienia, że kler powinien uszanować zarządzenia władz państwowych zachowując postawę neutralną". Dowodem na to miał być fakt, że odmówił udziału w spotkaniu zorganizowanym przez siostry zakonne z Gdyni, bo mogłoby to zostać uznane za zgromadzenie publiczne ${ }^{11}$.

W sobotę 23 I 1971 r. odbyło się zapowiadane w grudniu spotkanie biskupa Edmunda Nowickiego z przewodniczącym Prezydium Wojewódzkiej Rady Narodowej Tadeuszem Bejmem. Rozpoczęło się o jedenastej trzydzieści i trwało pięćdziesiąt minut ${ }^{12}$. Uczestniczyli w nim również ks. Jan Majder, wikariusz parafii „Gwiazda Morza” w Sopocie, i kierownik Wydziału do Spraw Wyznań Jan Szewczyk. Głównym celem rozmów było nakłonienie

dni prosimy Boga Ojca Naszego o opiekę nad Narodem naszym za pośrednictwem Matki naszej i królowej Polski". Zarządzenie to zostało podpisane przez kanclerza kurii ks. Kazimierza Mirynowskiego oraz wikariusza generalnego ks. Bernarda Polzina. Pod dokumentem widnieje data 17 grudnia, co wyjaśnia odniesienie modlitwy jedynie do wydarzeń w Gdańsku.

${ }^{8}$ AIPN Gd, 003/14, t. II, Meldunek dot. sytuacji na terenie woj. gdańskiego w dn. 20 XII 1970, k. 103.

${ }^{9}$ AIPN Gd, 299/141, Notatka służbowa, 22 XII 1970, k. 394-395.

${ }^{10}$ AIPN Gd, 0046/225, t. III, Informacja na temat sytuacji w Trójmieście, Gdańsk, 21 XII 1970, k. 215.

${ }^{11}$ Ibidem, Informacja dot. stanowiska biskupów i kurialistów w Pelplinie w związku z wydarzeniami w Trójmieście, k. 73.

12 APG, KW PZPR, 2384/1862, Notatka służbowa, Gdańsk, 30 I 1971, k. 91. 
biskupa do wydania polecenia proboszczom i pozostałym duchownym diecezji gdańskiej, by w najbliższą niedzielę, to jest 14 stycznia, w czasie mszy św. nakłaniali wiernych do zachowania spokoju oraz „lepszego zaangażowania społeczeństwa Wybrzeża w wykonywanie pracy zawodowej","

Na początku rozmowy Bejm poinformował biskupa o tym, że z polecenia władz wojewódzkich przeprowadzane są rozmowy przedstawicieli Miejskich Rad Narodowych z duchownymi Trójmiasta. Celem tych rozmów miało być zachęcenie księży do apelowania $\mathrm{z}$ ambon o spokój i rozsądek oraz normalną pracę. Przewodniczący PWRN przekonywał biskupa Nowickiego, że tylko w ten sposób można poprawić poziom życia ludzi pracy. W odpowiedzi usłyszał, że Kościół od zawsze akcentował zasadę pokoju w społeczeństwie. „Pan przewodniczący zwraca się do nas - mówił - abyśmy włączyli się do tych spraw, ale my mamy określone przeszkody. Swego czasu chwaliłem władzę za to, co nam zrobiła dobrze. Dostaliśmy argument do ręki. Teraz nam takiego instrumentu brakuje". Przywołał przy tym przykład ks. Józefa Waląga, któremu powyższych wskazań nie może zalecić, gdyż władza ukarała go za nieskładanie sprawozdań z działalności punktów katechetycznych (zabrano mu szafę i lodówkę), oraz niewymienionego z nazwiska w notatce duchownego z powiatu nowodworskiego, który doświadczył przykrości z tego samego powodu. Hierarchowie zabraniali bowiem składania sprawozdań. Chcąc zachęcić hierarchę do kontynuowania rozmowy, a jednocześnie przekonać o zasadności jej prowadzenia, Bejm postanowił od razu rozwiązać wymieniony problem pierwszego z duchownych i obiecał rekompensatę (przedmioty należące do niego zostały już na licytacji sprzedane). W późniejszym terminie obiecał również zająć się sprawą drugiego księdza. Gest ten dobrze ilustruje działania władz w stosunku do Kościoła - pokazuje bowiem pozorowaną gotowość do ustępstw, przy jednoczesnym zachowaniu kontroli nad omawianymi kwestiami. I właśnie z takiej pozycji zarówno na szczeblu centralnym, jak i wojewódzkim partia zamierzała realizować swoją politykę przywracania porządku i spokoju wśród mieszkańców Wybrzeża.

Prawdopodobnie wiedział o tym biskup Nowicki, wysuwając kolejne postulaty. Mógł więc świadomie sondować zamierzenia partii. W kolejnej wypowiedzi znów przywołał dwa przykłady, tym razem z zakresu budownictwa sakralnego. Pierwszym była sprawa o zwrot kościoła św. Stanisława we Wrzeszczu, drugim prośba o zatwierdzenie erygowania nowej parafii na Przymorzu. Bejm tym razem nie dał jednoznacznej odpowiedzi, choć stwierdził, iż pierwsza kwestia jest na dobrej drodze do rozwiązania, prosząc o nierozgłaszanie tej informacji wśród wiernych. Natomiast sprawa świątyni na Przymorzu miała zostać rozpatrzona w ciągu trzydziestu dni — to oczywiście nie mogło zadowolić biskupa Nowickiego ${ }^{14}$.

Argumentem, jaki przewodniczący PWRN wysuwał wobec biskupa, była rzekoma uległość władz w kwestii budownictwa sakralnego. Kościół gdański w ciągu ostatnich lat otrzymał zgodę na odbudowę świątyń św. Barbary, św. Katarzyny oraz św. Trójcy, a także erygowanie św. Brygidy. Biskupowi Edmundowi Nowickiemu zależało na stworzeniu nowe-

\footnotetext{
${ }^{13}$ Ibidem, k. 90.

${ }^{14}$ APG, KW PZPR, 2384/1862, Notatka służbowa, Gdańsk, 30 I 1971, k. 91. Warto wspomnieć w tym miejscu o dość znamiennym fakcie swoistego „rozgrywania” przez WdSW sprawy kościoła na Przymorzu. Już w połowie 1968 r. podkreślano, że rezygnacja z jego budowy nie jest możliwa, co było związane ze stopniową rozbudową dzielnicy. Wobec tego zalecano wybranie miejsca peryferyjnego, które wprawdzie nie będzie narzucać ograniczeń przestrzennych (liczono się z wybudowaniem dużej świątyni), ale w miarę rozbudowy osiedla kościół znajdzie w centrum Przymorza, co będzie stanowiło kontrargument dla ewentualnych planów budowy nowej świątyni. Z kolei gęsta zabudowa uniemożliwiałaby dobudowanie dodatkowej kaplicy. AIPN Gd, 299/91, Notatka uzupełniająca do informacji na temat perspektyw budownictwa sakralnego w Gdańsku, Gdańsk, 20 VII 1968, k. 10-11.
} 
go katolickiego periodyku, ale władze zgodziły się na jednorazowy egzemplarz specjalnego opracowania wzorem sąsiednich diecezji chełmińskiej i warmińskiej. Zadeklarowały jednocześnie gotowość udzielenia pomocy przy jego wydaniu ${ }^{15}$.

$\mathrm{Z}$ rezultatów rozmowy biskup gdański nie mógł wyjść w pełni usatysfakcjonowany. Jej efektem był sposób, w jaki ustosunkował się do najważniejszego z żądań stawianych przez Bejma - zaangażowania duchowieństwa diecezjalnego w apelowanie o spokój. Biskup obiecał, że „na prośbę p. Przewodniczącego postara się zadziałać roztropnie i skutecznie”. Ponieważ było już za późno na wydanie specjalnej kurendy, proboszczowie jeszcze tego samego dnia zostali poinformowani telefonicznie ${ }^{16}$.

Podobne postulaty Kościół gdański wysuwał na kolejnych konferencjach w PWRN. Na jednym z takich spotkań, które odbyło się 9 lutego, prowadzący rozmowę w imieniu kurii biskup pomocniczy Lech Kaczmarek ${ }^{17}$ akcentował potrzebę budowy nowych kościołów na Przymorzu i Stogach, rozbudowę istniejącego w Jelitkowie oraz domagał się podjęcia działań w sprawie zwrócenia kościoła św. Stanisława. Pojawił się również postulat podzielenia rozległej parafii Najświętszego Serca Jezusowego we Wrzeszczu — część podległych jej ulic miałoby zostać włączone do nowej parafii utworzonej z kościoła garnizonowego św. Piotra i Pawła ${ }^{18}$. Biskup Kaczmarek wiedział, że odzyskanie podległej Ministerstwu Obrony Narodowej świątyni będzie niemożliwe, zwłaszcza że zgoda władz na utworzenie parafii nie oznaczała zgody na powołanie parafii cywilnej. Kolejnym punktem spotkania było omówienie niewyjaśnionej kwestii zamieszczonego w piśmie „Argumenty” artykułu szkalującego biskupa Edwarda O'Rourke ${ }^{19}$. W odniesieniu do wszystkich przedkładanych postulatów biskup Kaczmarek słyszał obietnice rychłego ich rozpatrzenia oraz podjęcia działań wyjaśniających $^{20}$. Osiem dni później Bejm wręczył mu decyzję o przekazaniu kurii kościoła św. Stanisława ${ }^{21}$.

Nie oznaczało to rzecz jasna rychłego zwrotu świątyni. Na posiedzeniu Zespołu Wojewódzkiego do spraw Kleru 4 lutego uzgodniono wprawdzie, że świątynia powinna zostać zwrócona kurii ze względu na ,relacje natury historyczno-politycznej”, ale z jej ostatecznym oddaniem należało się wstrzymywać. Miała ona stanowić swego rodzaju element przetargowy w rozmowach, jakie planowano przeprowadzić w kolejnych miesiącach ${ }^{22}$. Na kolejne spotkanie do PWRN biskup Kaczmarek przybył w kwietniu, by ponownie usłyszeć o braku możliwości podejmowania wiążących decyzji w sprawie budownictwa sakralnego ${ }^{23}$.

${ }^{15}$ APG, KW PZPR, 2384/1862, Notatka służbowa, Gdańsk, 30 I 1971, k. 91.
${ }^{16}$ Ibidem.
${ }^{17}$ W rozmowach ze względu na stan zdrowia nie mógł już uczestniczyć biskup Nowicki.
${ }^{18}$ Dopiero w czerwcu 2009 r. z parafii Najświętszego Serca Jezusowego wydzielono parafię cywilno-
wojskową pw. Matki Odkupiciela przy kościele św. Piotra i Pawła.
${ }^{19}$ Edward Aleksander Władysław O’Rourke (1876-1943), od 1922 r. administrator apostolski Wolnego Miasta Gdańska, pierwszy biskup diecezjalny gdański w latach 1926-1938.

${ }^{20}$ W lutowej konferencji oprócz biskupa Lecha Kaczmarka uczestniczyli księża Bernard Polzin i Wiesław Lauer, a po stronie PWRN kierownik WdSW Jan Szewczyk i jego zastępca Józef Mazur oraz przedstawiciele wydziałów Finansowego Bogusław Kopczyński i Budownictwa, Urbanistyki i Architektury Zbigniew Smoczyński, zob. AIPN Gd, 299/119, Notatka służbowa, 19 II 1971, k. 150-152.

${ }^{21}$ APG, KW PZPR, 2384/1862, Notatka służbowa, Gdańsk, 18 II 1971, k. 102.

${ }^{22}$ APG, KW PZPR, 2384/1781, Protokół z posiedzenia Zespołu Wojewódzkiego d/s Kleru odbytego w dniu 4 II 1971 r. (z udziałem Zenona Jundziłła, Tadeusza Bejma, Stanisława Presia, Jana Nikołajewa, Jana Mariańskiego, Józefa Żyty, Mariana Lewandowskiego, Kazimierza Dudka, Jana Szewczyka i Edmunda Lindy), k. 131, 136.

${ }^{23}$ AIPN Gd, 299/119, Notatka służbowa, 10 V 1971, k. 154. 
Przedstawiciele kurii chełmińskiej, gdańskiej i warmińskiej w pierwszych miesiącach 1971 r. zgłaszali plany budowy pięciu kościołów, rozbudowy trzech kolejnych oraz remontu pięciu starych budowli sakralnych. Zaprezentowali również plan budowy czterech kaplic, jedenastu nowych plebanii i budynków gospodarczych, a także wyrażali potrzebę utworzenia nowych parafii ${ }^{24}$.

Konferencje, jakie odbywały się w Prezydium Wojewódzkiej Rady Narodowej, służyły bardziej podkreślaniu pozycji wojewódzkich władz wobec kurii biskupiej w Gdańsku niż rzeczywistej normalizacji stosunków. Przemawia za tym kontynuowanie rozmów w siedzibie WRN przy jednoczesnym traktowaniu biskupów niemal jak interesantów. Odwlekanie decyzji dotyczących kwestii istotnych z punktu widzenia kurii miało swój głęboki sens. W lipcu sytuacja w kraju była już w miarę stabilna, na kolejnym spotkaniu omawiano plan inwestycyjny kurii. Z osiemnastu postulatów dotyczących budowy bądź rozbudowy kościołów i budynków gospodarczych na terenie diecezji tylko cztery zostały przez władze rozpatrzone pozytywnie ${ }^{25}$.

Pewnym przykładem świadczącym o przybraniu zachowawczej taktyki w rozmowach z władzami wojewódzkimi była sprawa ks. Henryka Jankowskiego. Gdy przewodniczący PWRN Tadeusz Bejm dowiedział się o jego pielgrzymce na Jasną Górę zorganizowanej w czerwcu 1971 r., niezwłocznie udał się na rozmowę do biskupa Kaczmarka. Miał wówczas skarżyć się na „niewłaściwą postawę ks. Jankowskiego w okresie, kiedy między władzami państwowymi a Kościołem toczy się dialog" ${ }^{26}$. W pielgrzymce organizowanej przez proboszcza parafii św. Brygidy wzięły udział osiemdziesiąt trzy osoby, w tym ośmiu stoczniowców i dziewięcioro członków rodzin. Na koszt ks. Jankowskiego do Częstochowy pojechała Gertruda Stojecka, wdowa po zabitym pod bramą Stoczni Gdańskiej Kazimierzu Stojeckim, którą Jankowski osobiście przedstawił kardynałowi Stefanowi Wyszyńskiemu ${ }^{27}$. Uczestnicy pielgrzymki przywieźli ze sobą na Jasną Górę jako wotum tablicę wykonaną z mosiądzu, na której wygrawerowali napis: „Od stoczniowców — grudzień 1970”. Biskup Kaczmarek miał ostro zareagować na zachowanie kapłana i przeprowadzić z nim rozmowę ${ }^{28}$. Nie był to, jak się wydaje, wynik zdenerwowania krnąbrnością przyszłego kapelana „Solidarności”, ale skutek obawy o naruszenie pewnego, założonego przez biskupa gdańskiego, porządku rozmów z Bejmem.

Biskup Kazimierz Kowalski na konferencji dziekanów i wicedziekanów diecezji chełmińskiej 9 II 1971 r. stwierdzał, że wydarzenia grudniowe były skutkiem rozprzestrzeniającego się ateizmu. Jednak stworzyły one taką sytuację, w której dostrzegalne są pozytywne skutki dla samego Kościoła. Przypominał o przypadkach prześladowania księży, choć wypada tutaj podkreślić, że te działania, jakkolwiek umyślne i uciążliwe, dotyczyły głównie

\footnotetext{
${ }^{24}$ AIPN Gd, 0046/350, t. VII, Sprawozdanie płk. Władysława Pożogi z okresu od 10 maja do 4 czerwca 1971 roku na ręce Ministra Spraw Wewnętrznych, k. 94-95.

${ }^{25}$ Biskup Kaczmarek uzyskał wówczas zgodę na rekonstrukcję sklepień gotyckich i remont hełmu wieży kościoła św. Katarzyny, remont kościoła filialnego w Myszewie (pow. Malbork), budowę plebanii kościoła św. Barbary (utrzymanie w mocy decyzji z 1968 r.), oraz budynku gospodarczego w parafii nowodworskiej. Plan inwestycyjny nie obejmował zaakceptowanych już projektów budowy kościoła na Przymorzu czy przejęcia budynku kościoła św. Stanisława. AIPN Gd, 299/119, Notatka służbowa, 5 VII 1971, k. 158-159. Tam także wykaz odmów, w kilku przypadkach podano uzasadnienie.

${ }^{26}$ AIPN Gd, 0046/350, t. VII, Pismo na ręce dyrektora Gabinetu Ministerstwa Spraw Wewnętrznych na temat stanu realizacji przedsięwzięć politycznych i operacyjnych przewidzianych planem działań SB po wydarzeniach grudniowych, 3 VII 1971, k. 107.

${ }^{27}$ Ibidem, Pismo na ręce dyrektora Gabinetu Ministerstwa Spraw Wewnętrznych, 3 VII 1971, k. 107.

${ }^{28}$ Ibidem, k. 124.
} 
kwestii podatkowych i budowlanych i nie przypominały już prześladowania z lat pięćdziesiątych. Biskup chełmiński w tej kwestii — według Służby Bezpieczeństwa — był optymistą. Wierzył w poprawę tej sytuacji w stosunkowo krótkim czasie, o czym utwierdzały go w przekonaniu ostatnie wypowiedzi Edwarda Gierka i Piotra Jaroszewicza. Przedstawił księżom postulaty Episkopatu Polski dotyczące zaniechania przez władze ingerencji w sprawy obsadzania stanowisk kościelnych i katechizacji, przywrócenia działalności niektórych świeckich organizacji przykościelnych oraz uchylenia zarządzenia dotyczącego prowadzenia ksiąg inwentarzowych. Miało to poprawić znacząco sytuację Kościoła ${ }^{29}$.

Nie znaczy to, że polscy biskupi darzyli nowe władze pełnym zaufaniem. Zalecali kapłanom ostrożność w wysnuwaniu zbyt pochopnych wniosków w kwestii pełnego porozumienia Kościoła z rządem. Jednocześnie zachęcali proboszczów, by określili potrzeby swoich parafii i przygotowali swoje żądania pod adresem władz zwłaszcza w kwestii budownictwa ${ }^{30}$. Zmiany w Biurze Politycznym bez wątpienia uspokoiły nastroje wśród księży. Nie ma natomiast jednoznacznej odpowiedzi na pytanie, czy o zachowawczości duchownych w czasie grudniowej rewolty zadecydowały wyłącznie cechy charakterologiczne. Nie można tego wykluczyć. Należy tu wspomnieć o dość ważnym aspekcie, który mógł wpłynąć na powściągliwość biskupów Edmunda Nowickiego i Kazimierza Kowalskiego. Na przełomie 1970 i 1971 r. byli to już starzy i schorowani ludzie — ten ostatni 20 grudnia nie mógł nawet uczestniczyć w ceremonii poświęcenia kaplicy franciszkanów w Gdyni, o której budowę tak zabiegal ${ }^{31}$. Należy przypuszczać, że obaj wychodzili z założenia, iż nieostrożne nawoływanie do sprzeciwu czy kontynuowania demonstracji mogłoby spowodować śmierć nie dziesiątek, a setek osób.

Do wyciszenia napiętej sytuacji niejednokrotnie włączali się gdyńscy duchowni, nawołując do uspokojenia nastrojów i powrotu do pracy ${ }^{32}$. Podobnie zachowywali się księża na terenie Gdańska. W większości świątyń w mniej lub bardziej bezpośredni sposób odwoływali się do wydarzeń na Wybrzeżu. W jednej z informacji dla Urzędu do Spraw Wyznań na temat opinii wśród duchownych wymieniano liczne nawoływania do modlitwy o spokój w kraju czy rozsądne załatwianie spraw między państwem a społeczeństwem, modlitwy w intencji ONZ oraz pokoju na świecie ${ }^{33}$.

Opinie aprobujące wystąpienia na Wybrzeżu wychodziły od młodszych księży, natomiast starsi zachowywali większy dystans. Ci ostatni obawiali się wojny domowej, w związku z czym wśród części z nich odnotowano nawet opinie aprobujące użycie wojska „do zaprowadzenia ładu i porządku" - przyczyną takiego podejścia był głównie strach przed wykorzystaniem wojsk sowieckich. Interwencja sowiecka mogłaby z kolei spowodować zachwianie pozycji Kościoła, „dlatego lepiej — mówili — że swoje sprawy załatwiamy we własnym gronie, choć są one przykre i bolesne" ${ }^{, 34}$.

\footnotetext{
${ }^{29}$ AIPN Gd, 299/34, Informacja na temat aktualnej sytuacji w Kościele rzymskokatolickim na terenie województwa gdańskiego, Gdańsk, 12 II 1971, k. 281.

${ }^{30}$ AIPN Gd, 0046/350, t. XVII, Meldunek dot. aktualnej sytuacji na terenie miasta Gdyni, 12 II 1971, k. 217-218.

${ }^{31}$ AIPN Gd, 0046/225, t. III, Informacja na temat sytuacji w Kościele w województwie gdańskim, Gdańsk, 22 XII 1970, k. 225.

32 AIPN Gd, 0046/350, t. VII, Informacja dotycząca kształtowania się sytuacji polityczno-operacyjnej w związku z akcją ,Jesień 70”, 1 X 1971, k. 52.

33 Archiwum Akt Nowych w Warszawie (AAN), Urząd do Spraw Wyznań (UdSW), 125/43, Informacje o reakcjach kleru gdańskiego i szczecińskiego na ostatnie wydarzenia na Wybrzeżu, 25 I 1971, k. 325.

34 Podobne opinie odnotowano wśród duchownych w Kartuzach, Sierakowicach i Kiełpinie, AIPN Gd, 0046/350, t. XVII, Informacja dot. postawy kleru w okresie wydarzeń grudniowych oraz zaistniałych zmian, k. 223.
} 
Za radą biskupów także duchowni posługujący poza Trójmiastem zachowywali się powściągliwie - w prywatnych rozmowach nie odnosili się do wydarzeń, jakie miały miejsce na Wybrzeżu. Według meldunków SB na tym tle wyróżniał się ks. Zygmunt Frost, wikary z Jastarni, który znajomym kapłanom przypominał, że po październiku 1956 r. władza zwróciła się do kardynała Wyszyńskiego i to samo zrobił nowy premier Piotr Jaroszewicz. Wobec tego wielu duchownych uważało, że fala protestów musi wpłynąć na poprawę sytuacji Kościoła w Polsce - wierzono, że wśród postulatów robotniczych pojawiać się będą żądania wprowadzenia nauki religii do szkół czy budowy nowych świątyń ${ }^{35}$. Jednocześnie, jak wynika z dokumentów, w rozmowach z wiernymi w czasie wizyt duszpasterskich księża do grudniowej rewolty odnosili się „,w sposób bardzo krytyczny i wrogi”36.

Nieco inna ocena pojawia się w raporcie SB: „Jak wynikało z naszego rozpoznania sytuacji operacyjnej po wydarzeniach grudniowych kler przyjął postawę wyczekującą. Nie włączał się aktywnie do zachodzących przemian, lecz w pełni aprobował wszystkie towarzyszące zmianom zjawiska. Księża, a zwłaszcza znani nam z negatywnej, wrogiej postawy zrozumieli zachodzące zmiany społeczno-polityczne w naszym kraju oraz wypowiedzi dostojników państwowych i partyjnych na temat regulacji stosunków między Państwem a Kościołem aprobujące współpracę całego społeczeństwa jako rezygnację z ideologii marksistowskiej i zrównanie jej z ideologią idealistyczną,"37.

Uczestnictwo w nocnych pogrzebach zamordowanych było szczególnie trudnym przeżyciem nie tylko dla rodzin, ale i kapłanów. Gdańscy biskupi obawiali się, że rodziny zabitych będą miały pretensje za udział duchownych w nocnych pogrzebach. Istniało również ryzyko, że prasa poda ten fakt do publicznej wiadomości — a to oznaczałoby oskarżenie o poddanie się naciskom władzy, pośrednio więc o pewną formę legitymizacji jej poczynań. Znany jest przypadek ks. Mieczysława Goździewskiego z Gdańska, który odmówił udziału w takim pogrzebie, wiadomo natomiast, że kapelan z kościoła garnizonowego przy ul. Matejki (podległego Ministerstwu Obrony Narodowej) uczestniczył w nocnych pochówkach ${ }^{38}$. Udziału w tych pogrzebach odmówił również inny, niewymieniony z nazwiska kapłan, o którym wspominał biskup Edmund Nowicki na spotkaniu z kapłanami diecezji gdańskiej w seminarium duchownym ${ }^{39}$. Biskupi chełmińscy nie wydali żadnych zaleceń $\mathrm{w}$ sprawie uczestnictwa kapłanów w nocnych ceremoniach pogrzebowych. W czasie tak zwanych rozmów ostrzegawczych przeprowadzanych przez funkcjonariuszy SB duchowni obiecywali, że nie dopuszczą do żadnych ,ekscesów” podczas pogrzebów ${ }^{40}$.

\footnotetext{
${ }^{35}$ Ibidem, k. 222.

${ }^{36}$ AIPN Gd, 0046/350, t. XVI, Ocena sytuacji operacyjnej powiatu Starogard Gd. za okres 1965-1970, Starogard Gdański, 2 III 1971, k. 130.

${ }^{37}$ AIPN Gd, 0046/165, t. II, Ocena stanu zagrożenia bezpieczeństwa powiatu gdańskiego, Pruszcz Gdański, 8 II 1972, k. 7.

${ }^{38}$ AIPN Gd, 0046/225, t. III, Informacja, Gdańsk 21 XII 1970, k. 210.

${ }^{39}$ AIPN Gd, 0046/26, t. I, Doniesienie TW „Mewa” z 23 XII 1970, k. 174.

40 Tak choćby przykład ks. Stanisława Frejlicha z Gdyni, AIPN Gd, 0046/225, t. III, Informacja na temat sytuacji w Trójmieście, Gdańsk, 21 XII 1970, k. 214. Abp Tadeusz Gocłowski wspominał po latach o pewnym księdzu, który został zmuszony do uczestnictwa w pogrzebie jednego z zamordowanych: „Kiedy mi o tym opowiadał, nie mógł opanować płaczu, jak czuł się podeptany nie tylko ten zabity, ale i on, który w pewnym sensie uczestniczył — oczywiście na prośbę rodziny - w nocy, w pogrzebie tego zabitego na ulicach Gdańska". Zob. Wypowiedź abpa Tadeusza Gocłowskiego podczas III Sesji konferencji, którą 15 XII 2007 roku zorganizowała Fundacja Centrum Solidarności, Konferencja. Grudzień '70-pamiętamy, Gdańsk 2007, s. 78.
} 
Decyzję o przełożeniu odczytywania listu o zagrożonym bycie narodu, co pierwotnie miało nastąpić 27 XII 1970 r., większość kapłanów uznała za w pełni uzasadnioną. Inni określali tę decyzję jako przejaw tchórzostwa ordynariuszy diecezjalnych. Wobec tego nie wszyscy podporządkowali się zarządzeniu biskupów ${ }^{41}$.

29 grudnia biskupi polscy wydali dokument Rada Główna Episkopatu Polski do wszystkich rodaków wspólnej Ojczyzny. List został odczytany na niedzielnych mszach 3 I $1971 \mathrm{r}$. Służba Bezpieczeństwa poddała kontroli połowę kościołów na terenie województwa gdańskiego - tych, w których występowało największe ryzyko wystąpień, a więc przede wszystkim w Trójmieście. Według danych Wydziału IV Komendy Wojewódzkiej Milicji Obywatelskiej treść listu przytoczono w 90 proc. świątyń na terenie województwa - niekiedy z dodatkowym komentarzem duchownych. Ogólnie księża w nawiązaniu do wydarzeń sprzed niespełna trzech tygodni apelowali o spokój i modlitwę za ofiary. Przykładowo w kościele oo. Zmartwychwstańców w Gdańsku-Wrzeszczu kapłan głoszący kazanie powiedział, że członkowie partii różnych szczebli i związków zawodowych powinni działać na rzecz poprawy sytuacji, a nie tylko czerpać z tego tytułu korzyści. Prosił o modlitwę za rządzących, aby ,wydawali pokojowe i sprawiedliwe decyzje" ${ }^{, 42}$.

Odnotowywano również przypadki, że księża sami inicjowali modlitwę za zmarłych. W kościele św. św. Piotra i Pawła w Jelitkowie padł apel o modlitwę za ofiary masakry w Gdańsku i Gdyni oraz osadzonych w więzieniach. Natomiast w kościele oo. Zmartwychwstańców modlono się za rządzących, by podejmowali sprawiedliwe decyzje. Z kolei wikariusz kościoła Chrystusa Króla w Gdańsku ks. Marian Szlagowski wzywał wiernych do modlitwy za „maltretowanych i bitych, siedzących w więzieniach, a szczególnie poległych od kul w mieście Gdańsku”,33. W kazaniu wygłoszonym 20 grudnia do młodzieży w kościele parafialnym pw. Matki Boskiej Bolesnej w Gdańsku proboszcz tejże parafii mówił: „W tym roku święta będziemy obchodzić w wielkiej tragedii, bólu i smutku. Bardziej boleśnie, niż w 1939 roku, bo w 1939 roku wkroczyły czołgi okupanta, a teraz nasi bracia”. Na kolejnej mszy mówił, ,że to, co się stało, musiało się stać, aby przyszłe pokolenia powiedziały, jak żyła Polska. Polska nie jest chuligańska, Polska jest chrześcijańska. Wiemy, o co chodzi, i nie musimy sobie tego wyjaśniać" ${ }^{44}$.

Niekiedy w sposób stanowczy i zdecydowany księża z ambon domagali się wyjaśnienia przyczyn masakry na Wybrzeżu. Na niedzielnej mszy 3 I 1971 r. w katedrze w Oliwie padło stwierdzenie, że do tragedii ,doprowadził brak dialogu między wszystkimi członkami rodziny społecznej w państwie"45" Tydzień później ks. Marian Szlagowski powiedział, że „wszystkie dzieci muszą uczęszczać na lekcje religii, jeżeli rodzice nie chcą, aby wychowały się na ateistów. Ateizm spowodował, że ludzie spod znaku Gomułki i Kliszki strzelali w grudniu

\footnotetext{
${ }^{41}$ W części parafii księża komentowali treść listu, a w parafii w Sulęczynie odczytano go na wszystkich mszach. AIPN Gd, 0046/350, t. XVII, Informacja dot. postawy kleru w okresie wydarzeń grudniowych oraz zaistniałych zmian, k. 223.

${ }^{42}$ AIPN Gd, 299/34, Informacja nt. zabezpieczenia imprez kościelnych w dniu 3 stycznia 1971 r. w województwie gdańskim, Gdańsk, 4 I 1971, k. 258-259. Niekiedy komentarze księży oparte były o plotki nieznajdujące potwierdzenia w faktach. Przykładem była wypowiedź jednego z księży w nawiązaniu do wspomnianego listu biskupów pt. Rada Główna Episkopatu Polski do wszystkich rodaków wspólnej ojczyzny podczas mszy 3 stycznia w kościele pw. św. Barbary w Gdańsku. Sugerował on, że w czasie „czarnego tygodnia” ginęły kobiety i dzieci.

${ }_{43}$ AIPN Gd, 299/34, Informacja nt. zabezpieczenia imprez kościelnych w dniu 3 stycznia 1971 r. w województwie gdańskim, Gdańsk, 4 I 1971, k. 259.

${ }_{44}$ AIPN Gd, 003/14, t. II, Meldunek dot. sytuacji na terenie woj. gdańskiego w dn. 20 XII 1970, k. 104.

${ }^{45}$ AIPN Gd, 299/34, Informacja nt. zabezpieczenia imprez kościelnych w dniu 3 stycznia 1971 r. w województwie gdańskim, Gdańsk, 4 I 1971, k. 259.
} 
do robotników, gdy ci wyszli na ulice domagać się swych podstawowych praw, a skutki tego oglądaliśmy na naszej gdańskiej ziemi”. Kazania tego wysłuchało blisko tysiąc osób. Nie umknęło ono uwadze bezpieki. Jego autor, wraz z proboszczem parafii, ks. Kazimierzem Kluzem, zostali natychmiast wezwani na „rozmowę o charakterze ostrzegawczym, "46.

Do grudniowych zajść nawiązywano w mniej lub bardziej bezpośredni na innych mszach w styczniu. Na jednym z nabożeństw w Gdyni głoszący kazanie redemptorysta podkreślił, że gdyńskie rodziny są przygnębione skutkami wydarzeń sprzed miesiąca. Miał również wyrazić nadzieję, że doczekają prawdziwej wolności sumienia i wyznania. Skrytykował przy tym członków partii, którzy ponad wiarę ceną sobie stanowiska. Po kazaniu koncelebrujący mszę zakonnik rozpoczął modlitwę za nowe władze, by pozwoliły na budowę nowego kościoła przy ul. Portowej ${ }^{47}$.

Zmiany w Biurze Politycznym duchowni przyjęli z pewną ulgą, ale ich niepokój wywoływały osoby Mieczysława Moczara i Stanisława Kociołka ${ }^{48}$. Nie znaczy to, że do nowego I sekretarza partii Edwarda Gierka nie podchodzono z rezerwą. Przeważała jednak radość z odejścia Władysława Gomułki. Równocześnie pojawiały się opinie, że po Gierku nie można spodziewać się wiele dobrego, bo na Śląsku „dość mocno «przykręcał śrubę» klerowi katolickiemu". Jego zapewnienia o tym, że w społeczeństwie jest miejsce zarówno dla wierzących, jak i niewierzących, traktowano jako blef, który stosował już Gomułka po dojściu do władzy w 1956 r. ${ }^{49}$ Jednak część księży upatrywała w tej wypowiedzi szansy na zwiększenie autonomii Kościoła $^{50}$. Upadek zaufania do rządzących oznaczał wzrost autorytetu Kościoła. Słusznie skomentował w jednym ze swoich kazań ks. Zieliński z Sopotu zwiększenie frekwencji na nabożeństwach, stwierdzajac, iż wielu ludzi „widzi w Kościele przywódcę narodu. Uznają oni stanowisko Kościoła, który jest przeciwny takiemu sposobowi rozwiązywania problemów, do jakiego uciekało się państwo strzelające do ludzi, którzy żądali chleba"51.

Jeszcze w grudniu 1970 r. do osób poszkodowanych w imieniu I sekretarza Komitetu Centralnego PZPR Edwarda Gierka i premiera Piotra Jaroszewicza przychodzili przedstawiciele miejskich i wojewódzkich rad narodowych, by wręczyć im jednorazowe zapomogi (osiemnaście rodzin pomordowanych otrzymało po 10 tys. zł, a ranni znajdujący się w szpitalach - po 5 tys. zł). Jak podaje Henryk Kula, urzędową ewidencję zmarłych zakończono

\footnotetext{
${ }^{46}$ Funkcjonariusze SB zabezpieczyli tego dnia 125 kościołów w województwie gdańskim, co stanowiło 60 proc. ogólnej liczby. Nie odnotowano żadnych „,negatywnych komentarzy”, z wyjątkiem wyżej przytoczonego. Przyczyną braku nawiązań do wydarzeń grudniowych był fakt, iż tego dnia odczytywano w kościołach list w związku z piątą rocznicą Soboru Watykańskiego II, toteż większość komentarzy duchownych dotyczyła odnowy w duchu posoborowym. Zob. AIPN Gd, 299/34, Informacja [dotycząca zabezpieczenia nabożeństw w województwie gdańskim], Gdańsk, 10 I 1971, k. 260.

${ }^{47}$ AIPN Gd, 299/18, Telefonogram do UdSW z 18 I 1971 z godz. 11.00, k. 42.

${ }^{48}$ AIPN Gd, 0046/225, t. III, Notatki ze spotkań z TW przeprowadzone przez pracowników Wydziału IV, Gdańsk, 22 XII 1970, k. 242.

${ }^{49}$ „O entuzjazmie świadczy fakt, że księża po usłyszeniu komunikatu o tej sprawie telefonowali wzajemnie do siebie dzieląc się tą informacją, a jednocześnie nie szczędzili wulgarnych epitetów pod adresem Wł. Gomułki”. AIPN Gd, 0046/350, t. XVII, Informacja dot. postawy kleru w okresie wydarzeń grudniowych oraz zaistniałych zmian, k. 223. Niektórzy po ogłoszeniu drukiem specjalnego numeru „Nowych Dróg”, organu KC, w którym zamieszczono materiały z VIII plenum, prosili nawet o udostępnienie im dodatkowych egzemplarzy, jak choćby ks. Adam Szczepański, a inni w ogóle postulowali zwiększenie nakładu periodyku. Zob. AIPN Gd, 299/2, Protokół z odbytego spotkania z administratorami parafii powiatu malborskiego w dniu 16 VI 1971, k. 227; ibidem, Informacja o przebiegu spotkań zbiorowych z księżmi, Gdańsk, 1 VII 1971, k. 234.

${ }^{50}$ AIPN Gd, 0046/350, t. XVII, Informacja dotycząca sytuacji ekonomiczno-politycznej, Kartuzy, 4 I 1971, k. 9.

${ }^{51}$ AIPN Gd, 299/18, Telefonogram do UdSW z 18 I 1971 z godz. 11.00, k. 42.
} 
z dniem 17 I 1971 r. Po tym okresie z urzędu nie zajmowano się losem przynajmniej kilkudziesięciu osób ciężko rannych, które pozostały w szpitalach, oraz tych, które leczyły się prywatnie",52. Łącznie z tytułu odszkodowań dla Trójmiasta przeznaczono blisko 5,85 mln zł, $\mathrm{z}$ czego niemal jedną trzecią otrzymali funkcjonariusze MO oraz żołnierze $\mathrm{WP}^{53}$.

Biskupi mieli świadomość, że wiele potrzebujących rodzin nie zgłaszało się po pomoc do władz ze strachu przed represjami. 21 grudnia ks. Bernard Polzin, wikariusz generalny kurii gdańskiej, skierował do duszpasterzy charytatywnych zalecenie, by odwiedzali oni rodziny ofiar oraz oferowali im zarówno wsparcie moralne, jak i materialne ${ }^{54}$. W związku z okresem wizyt duszpasterskich duchowni w diecezjach gdańskiej i chełmińskiej starali się zbierać informacje na temat rzeczywistej liczby zabitych i poszkodowanych. Służyło to ustaleniu skali pomocy materialnej osobom, które odniosły obrażenia bądź straciły bliskich w grudniu 1970 r. ${ }^{55}$

Do składania ofiar zachęcano wiernych w odczytywanym na mszach 28 stycznia liście biskupów, podpisanym przez kardynała Stefana Wyszyńskiego. „Modlitwy nasze poprzemy groszem ofiarnym, choćby skromnym, który złożymy jako «dar ołtarza» w czasie nabożeństw dla rodzin pozbawionych swych żywicieli. Będzie to widzialny znak naszej wspólnoty chrześcijańskiej i współczucia” — głosił tekst odezwy ${ }^{56}$. Wśród mieszkańców Gdyni pojawiały się plotki, jakoby Polonia na Zachodzie miała organizować zbiórki pieniędzy dla rodzin ofiar Grudnia 1970. Polacy mieszkający za granicą mieliby przekazać fundusze prymasowi, a ten rozdzieliłby je między poszczególne parafie na Wybrzeżu ${ }^{57}$. Pogłoski te nie znajdują jednak odzwierciedlenia w zachowanych źródłach.

Na wspomnianej powyżej konferencji dziekanów i wicedziekanów diecezji chełmińskiej z udziałem biskupa Kazimierza Kowalskiego, która odbyła się 9 II 1971 r., padło zalecenie, by w czasie mszy 14 lutego, kiedy na polecenie prymasa Wyszyńskiego odmawiano Modlitwę Narodu za Ojczyznę, we wszystkich kościołach diecezji chełmińskiej zbierano datki dla rodzin ofiar. Uzgodniono, że datki te miały być przekazane do dyspozycji kurii jako sumy przechodnie, co zwolniłoby je $\mathrm{z}$ podatku ${ }^{58}$. Miały one zostać rozdzielone na początku marca. Natomiast ze względu na śmierć biskupa Edmunda Nowickiego kwestia rozdysponowania zapomóg pomiędzy rodziny ofiar oraz rannych w Gdańsku została odłożona na czas po jego pogrzebie, który odbył się 14 marca $^{59}$.

${ }^{52}$ H. M. Kula, Grudzień 1970. „Oficjalny” i rzeczywisty, Gdańsk 2006, s. 640, 641; APG, KW PZPR, nr 1848, Informacja sporządzona przez Urząd Spraw Wewnętrznych Prezydium Wojewódzkiej Rady Narodowej, dotycząca realizacji zadań wynikających z Uchwały Nr 215/70 Rady Ministrów z dnia 30 grudnia 1970 r. w sprawie doraźnych świadczeń pieniężnych dla osób poszkodowanych w związku z wypadkami grudniowymi 1970 r. na Wybrzeżu Gdańskim, 19 II 1972, k. 229.

${ }_{53}$ APG, KW PZPR, nr 1848, Zestawienie niektórych ważniejszych danych dot. wypłaty odszkodowań i rent dla osób poszkodowanych w czasie wypadków grudniowych w Gdańsku, k. 185.

${ }^{54}$ AIPN Gd 003/14, t. XXII, Informacja, 21 XII 1970, k. 118.

${ }^{55}$ AIPN Gd 0046/350, t. VII, Informacja [dot. kształtowania się sytuacji w związku z akcją „Jesień 70”], 1 X 1971, k. 52.

${ }^{56}$ Biskupi polscy wzywaja caty naród do modlitwy za ojczyznę, w: Listy pasterskie Episkopatu Polski 1945-1974, Paryż 1975, s. 622.

${ }^{57}$ Pojawiały się nawet konkretne liczby. Według tych informacji Polonia w Anglii zebrała podobno 2 tys. funtów. Podobne zbiórki mieli również organizować Polacy mieszkający w Stanach Zjednoczonych czy Skandynawii. Zob. AIPN Gd, 0046/350, t. XVII, Meldunek dot. aktualnej sytuacji w kluczowych zakładach pracy, Gdynia, 21 I 1971, k. 58.

${ }^{58}$ AIPN Gd, 299/34, Informacja na temat aktualnej sytuacji w Kościele rzymskokatolickim na terenie województwa gdańskiego, Gdańsk, 12 II 1971, k. 283.

59 AIPN Gd, 299/34, Informacja na temat aktualnej sytuacji w Kościele rzymskokatolickim w województwie gdańskim, Gdańsk, 25 III 1971, k. 290. 
23 marca biskup pomocniczy chełmiński Bernard Czapliński, infułaci ks. Roman Górski i ks. Franciszek Jank omówili zasady przydziału zasiłków poszkodowanym w grudniu. Ustalili, że na terenie diecezji chełmińskiej zamieszkiwały rodziny ośmiu zabitych i czterdzieści cztery osoby, które odniosły obrażenia ${ }^{60}$. Podjęto decyzję, że wszyscy bez wyjątku otrzymają zapomogi — średnio 5 tys. zł, choć przeważnie były to sumy od 4 do 8 tys. W szczególnych wypadkach przyznawano pomoc w wysokości 20, a nawet 50 tys. zł. Wysokość tej pomocy uzależniono od wielu czynników. Podstawowym kryterium były warunki materialne poszkodowanego, a także liczba osób w rodzinie niezdolna do pracy i stopień kalectwa stwierdzony świadectwem lekarza ${ }^{61}$.

Łącznie na ten cel w pierwszych miesiącach po tragicznych wydarzeniach przeznaczono 260 tys. w samym Gdańsku - przy czym proboszczowie mogli regulować wysokość zapomóg, ale w ramach ustalonych wcześniej limitów. Oczywiście wiele osób nie zgłaszało się po pomoc do parafii z obawy przed aresztowaniem. Mieli tego pełną świadomość administratorzy parafii, którzy jeszcze w 1972 r. przyznawali pomoc materialną najbardziej potrzebującym. Całkowita wysokość funduszu dla całego województwa gdańskiego wyniosła 600 tys. zł. Podkreślano, że nie wszyscy otrzymali od państwa odszkodowania. Postanowiono jednak bez względu na to udzielać zapomóg każdemu, kto się zgłosi. Proboszczowie postulowali zachowanie części pieniędzy w rezerwie, podejrzewano bowiem, że nie zgłosili się wszyscy poszkodowani ${ }^{62}$. Tej pewności nie mieli jeszcze, zamykając bilans na rok $1971^{63}$.

Pieniądze były przechowywane w kuriach biskupich i księgowane jako sumy przechodnie. Następnie przekazywano je radom charytatywnym poszczególnych parafii i dalej proboszczom. Ci zaś mieli wręczać je potrzebującym w obecności co najmniej jednego świadka. Zabieg z wykorzystaniem parafialnych rad charytatywnych był potrzebny po to, by pracownicy Wydziału Finansowego PWRN nie zażądali odprowadzenia podatków od zebranych sum ${ }^{64}$.

W centrum zainteresowania bezpieki znalazły się też święta kościelne. Przykładowo podczas uroczystości z okazji Bożego Ciała w 1971 r. w kilku dekoracjach eksponowano kotwicę jako symbol nadziei. Jednocześnie, jak szacowano, nastąpił piętnastoprocentowy wzrost frekwencji w procesjach na terenie diecezji gdańskiej w porównaniu z rokiem ubiegłym ${ }^{65}$. Niekiedy rewolta grudniowa stawała się dla duchownych inspiracją w dość — zdawałoby się - nieoczekiwanych sytuacjach. Mowa tu o postawie nowodworskiego duchownego, ks. Wiesława Gawlika, który bez uzgodnienia z władzami zmienił trasę procesji na Boże Ciało. Na pytanie, dlaczego to zrobił, odparł że „najlepiej o tym świadczą wypadki grudniowe, że dopiero trzeba uderzyć pięścią w stół, by uzyskać to, co się chce, a przecież [...] wtedy księża nie występowali przeciw władzy, która i tak okazała się bezsilna"66.

${ }^{60}$ Dane te powstały wyłącznie w oparciu o zgłoszenia, jakich poszkodowani dokonywali w swoich parafiach. Szerzej na temat problemów z ustaleniem dokładnej liczby ofiar Grudnia zob. W. Kwiatkowska, Ofiary, w: To nie na darmo... Grudzień '70 w Gdańsku i Gdyni, red. M. Sokołowska, Pelplin 2006, s. 67-90. ${ }^{61}$ AIPN Gd, 0215/15, Informacja na temat działalności gdańskiej kurii biskupiej, Gdańsk, 4 XII 1971, k. 63 .

${ }^{62}$ AIPN Gd, 299/34, Informacja na temat aktualnej sytuacji w Kościele rzymskokatolickim w województwie gdańskim, Gdańsk, 25 III 1971, k. 289.

${ }^{63}$ AIPN Gd, 0215/15, Informacja na temat działalności gdańskiej kurii biskupiej, Gdańsk, 4 XII 1971, k. 62.

${ }^{64}$ AIPN Gd, 299/34, Informacja na temat aktualnej sytuacji w Kościele rzymskokatolickim w województwie gdańskim, Gdańsk, 25 III 1971, k. 289.

${ }^{65}$ AIPN Gd, 0046/350, t. VII, Pismo na ręce dyrektora Gabinetu Ministerstwa Spraw Wewnętrznych, 3 VII 1971, k. 108.

${ }^{66}$ AIPN Gd, 0215/15, Notatka służbowa z przeprowadzonej rozmowy w dniu 18 VI 1971 z księdzem Wiesławem Gawlikiem, k. 31. 
Przed uroczystościami z okazji święta Wszystkich Świętych w 1971 r. gdańska SB przeprowadziła czterdzieści dwie rozmowy profilaktyczne z duchownymi z Gdańska, Gdyni i Elbląga. Zabezpieczone zostały nabożeństwa w połowie kościołów na terenie województwa, w tym niemal wszystkie w Trójmieście. Postawę księży oceniano jako „lojalną” z wyjątkiem trzech przypadków. Ks. Wojciech Feliks Wołos z parafii pw. Podwyższenia Krzyża na gdańskim Chełmie w jednym z kazań nawiązywał do Poznania '56 i Grudnia '70 jako ,skutków ograniczania wolności”. Nawoływał przy tym do odważnej postawy w walce o umacnianie wolności ${ }^{67}$. Całe kazanie dotyczyło dwóch aspektów jej ograniczania. Dobrą jego stroną miała być dbałość milicji o porządek, złą - jej postawa w Gdańsku i Gdyni w Grudniu $1970^{68}$. Ks. Zygmunt Pietrasiński, wikary parafii pw. św. Leona w Wejherowie, tłumaczył natomiast, że podział na wierzących i niewierzących, który stosuje państwo, uderza w tych pierwszych. Z kolei ks. Waldemar Piepiórka z Kartuz krytykował ideologię marksistowską ${ }^{69}$. W związku uroczystością Wszystkich Świętych kontroli poddane zostały cmentarze, na których pochowane były ofiary Grudnia ${ }^{70}$.

Jeden z sopockich duchownych zarejestrowany przez Służbę Bezpieczeństwa jako TW ps. „Wolny” donosił, że prymas miał „w sposób rygorystyczny” zabraniać księżom odprawiania modlitw za poległych w pierwszą rocznicę grudniowej masakry. Według jego doniesienia ks. Bernard Polzin zastrzegał w czasie skupienia dla księży diecezji gdańskiej, iż kardynał Stefan Wyszyński oraz biskupp gdański Lech Kaczmarek „nie życzą sobie, aby w czasie intencji za dusze zmarłych nie używać okoliczności śmierci, a tylko ograniczyć się do podania daty i nazwiska. Mówiąc o tym wyraził się, że nie «można rozdrapywać ran»" ". Podobny donos złożył TW ps. „Janusz”, który twierdził, że miał tę informację usłyszeć od ks. Polzina podczas odprawy dekanalnej księży z dekanatu nowostawskiego 9 XII 1971 roku. Prymas miał również zabraniać nawiązywania do obrad i wyników VI Zjazdu PZPR ${ }^{72}$.

W oficjalnym komunikacie kurii gdańskiej dla duchowieństwa ogłoszonym przez ks. Polzina stwierdzano, że ,zabrania się księżom ogłaszania w trakcie odprawiania mszy

${ }^{67}$ AIPN Gd, 0046/350, t. VII, Informacja na temat stanu realizacji przedsięwzięć politycznych i operacyjnych przewidzianych planem działań SB po wydarzeniach grudniowych, 4 XI 1971, k. 163.

${ }^{68}$ AIPN Gd, 299/34, Informacja na temat aktualnej uroczystości kościelnych w dniu 1 listopada 1971 r., Gdańsk, 2 XI1971, k. 370.

${ }^{69}$ AIPN Gd, 0046/350, t. VII, Informacja na temat stanu realizacji przedsięwzięć politycznych i operacyjnych przewidzianych planem działań SB po wydarzeniach grudniowych, 4 XI 1971, k. 163.

${ }^{70}$ AIPN Gd, 0046/350, t. XXIX, Plan operacyjno-fizycznego zabezpieczenia kluczowych obiektów gospodarczych i kontrolowanych środowisk w okresie od 12 XII do 16 XII 1973 na terenie miasta Gdańska, k. 13.

${ }^{71}$ AIPN Gd, 0046/350, t. XIX, Pismo na ręce zastępcy Komendanta Wojewódzkiego MO ds. Służby Bezpieczeństwa w Gdańsku, Malbork, 11 XII 1971, k. 268. Samo sformułowanie na temat „rozdrapywania ran" brzmi na tyle interesująco, że warto przyjrzeć się mu nieco bliżej. W korespondencji z prymasem w kwietniu 1972 r. Piotr Jaroszewicz użył podobnego wyrażenia w odniesieniu do działania hierarchii Kościoła: „Jątrzenie zabliźnionych ran i wykorzystywanie tych tragicznych doświadczeń do jakichkolwiek celów nie służy interesom naszego społeczeństwa i kraju”. Kardynał poczuł się wyraźnie dotknięty tym oskarżeniem: „Pan premier w sposób bardzo bolesny dla mnie pisał o «jątrzeniu zabliźnionych ran itd.». Mógłbym tej sprawy nie ruszać, ale uważam, że leżałoby to poniżej godności obywatela wolnego. Pan premier nie może mi przypisywać takich intencji”. Zob. AAN, UdSW, 149/1, List premiera Piotra Jaroszewicza do kardynała Stefana Wyszyńskiego, 14 IV 1972, k. 175; ibidem, List kardynała Stefana Wyszyńskiego do premiera Piotra Jaroszewicza, 15 V 1972, k. 172.

${ }^{72}$ Wiele wskazuje na to, że takie stanowisko ks. Bernard Polzin prezentował jeszcze przed oficjalnym ogłoszeniem go przez kurię. AIPN Gd, 0046/350 t. XIX, Pismo na ręce zastępcy Komendanta Wojewódzkiego MO ds. Służby Bezpieczeństwa w Gdańsku, Malbork, 11 XII 1971, k. 264. 
w intencji osób, które zginęły podczas ubiegłorocznych wydarzeń grudniowych faktu, że zgon określonej osoby nastąpił podczas wspomnianych wydarzeń. Jest to życzenie bpa Kaczmarka, jak również kard. Wyszyńskiego [...]. Uważają, że nie ma potrzeby rozgrzebywania starych ran”. Według cytowanego dokumentu prymas wychodził z założenia, że ,publiczne poruszanie problemów związanych z wydarzeniami grudniowymi miałoby niekorzystny wpływ na przebieg rozmów Państwo-Kościół" "73. Pozostaje pytaniem bez odpowiedzi, na ile była to inicjatywa biskupa Kaczmarka, a na ile prymasa. Należy jednak podkreślić, że zalecenia hierarchów były skierowane wyłącznie do księży z diecezji gdańskiej, natomiast nie padły one podczas spotkań przedstawicieli duchowieństwa diecezji chełmińskiej, do której wówczas należała Gdynia. Świadczą o tym fakcie relacje z nabożeństw odprawianych w Gdyni w związku z pierwszą rocznicą tragicznych wydarzeń.

O ile więc w grudniu 1971 r. biskup gdański Lech Kaczmarek wydał zakaz wymieniania przyczyn śmierci ofiar rewolty grudniowej na mszach rocznicowych, o tyle obostrzenia te, co istotne, nie obowiązywały w kościołach diecezji chełmińskiej. Już 12 grudnia zapowiadano msze żałobne w rocznicę masakry w Gdyni — w tamtejszych kościołach franciszkanów, jezuitów, a także kościele pw. Najświętszego Serca Pana Jezusa w Gdyni oraz św. Leona w Wejherowie. W tym ostatnim przypadku w obecności około siedemdziesięciu wiernych odprawiono tzw. mszę cichą w intencji wszystkich ofiar, z mszy w kościele franciszkanów zrezygnowano w ogóle. W kościele pw. św. Jerzego w Sopocie odbyła się msza w intencji zabitego studenta Waldemara Zajczonki, na której obecna była tylko rodzina zmarłego $^{74}$.

Msza w kościele NSPJ odprawiana była za Zygmunta Politę oraz pozostałe ofiary. Modlitwę w ich intencji odprawił ks. Hilary Jastak w asyście pięciu księży. Kazanie wygłoszone przez ks. Ryszarda Osińskiego dotyczyło Męki Pańskiej i bezpośrednio nie nawiązywało do wydarzeń sprzed roku. W tym uroczystym nabożeństwie uczestniczyło około tysiąca osób, z czego ponad jedną trzecią stanowiła młodzież ${ }^{75}$.

Choć zgromadziła cztero-pięciokrotnie mniej wiernych, najbardziej wymowny charakter miała msza odprawiona w kościele oo. Jezuitów. Przed ołtarzem wystawiono katafalk przybrany białymi i czerwonymi kwiatami oraz biało-czerwoną wstęgą. Jeden z dwóch celebransów, ks. Ignacy Karpiński, nadmienił, że msza ,jest za tych, co przelali krew walcząc o słuszną naszą wspólną sprawę”. Do zgromadzonych skierował pytanie: „Czy opłaciła się ta krew? Czy i co zrobiliśmy, by zapanowała miłość wszystkich ludzi?"

Według opracowań funkcjonariuszy aparatu represji księży dzielono na zdecydowanie wrogich, realizujących bez żadnych zastrzeżeń zalecenia hierarchii — tych była zdecydowana mniejszość — oraz na pozostałych — księży o postawie umiarkowanej. Ci z kolei mieli wprawdzie realizować wytyczne episkopatu, zależnie jednak od okoliczności w całości bądź częściowo, tak jednak, by nie „,narażać się” władzy ${ }^{77}$. Funkcjonariusze SB starali się wykorzystywać wszelkiego rodzaju konflikty i spory między proboszczami a wikariuszami oraz między proboszczami a wiernymi. Polecano nagradzać lojalnych księży udzielać pomocy w uzyskiwaniu ulg podatkowych, dając im tym samym do zrozumienia,

\footnotetext{
${ }^{73}$ AIPN Gd, 299/34, Informacja na temat ważniejszych wydarzeń w środowiskach kleru rzymskokatolickiego w województwie gdańskim w miesiącu grudniu 1971 roku, Gdańsk, 20 XII 1971, k. 397.

${ }^{74}$ Ibidem, k. 402-403.

75 Ibidem, k. 402.

${ }^{76}$ Ibidem, k. 403.

77 AIPN Gd, 0046/165, t. I, Ocena stanu zagrożenia bezpieczeństwa powiatu gdańskiego, Pruszcz Gdański, 4 III 1971, k. 10.
} 
że lojalność wobec władzy jest zwyczajnie opłacalna. W ten sposób odciągano duchownych od wpływów kurii ${ }^{78}$.

Nieco przesadnie brzmi w tym kontekście opinia urzędników UdSW, którzy nie bez satysfakcji pisali: „W wyniku naszego oddziaływania na kler parafialny, dokonują się wśród niego pozytywne zmiany polityczne. Kler w swej masie pragnie normalizacji stosunków z Państwem i odnosi się krytycznie do linii kierownictwa Episkopatu dowodem takiego stanowiska kleru parafialnego jest fakt, że około 80\% proboszczów w czasie ostatnich rozmów z przewodniczącymi PPRN oświadczyło, iż nie będzie czytało listu Episkopatu o «zagrożeniu bytu Narodu»",79.

Postawa duchownych w porównaniu z okresem sprzed Grudnia 1970 w pewnych względach ewoluowała. Poprzednio „wroga działalność” księży polegała przede wszystkim na wygłaszanej z ambon krytyce polityki władz centralnych i wojewódzkich. Do tejże wrogiej działalności zaliczano również niepodporządkowywanie się zarządzeniom w zakresie rejestracji punktów katechetycznych oraz niewłaściwe prowadzenie ksiąg inwentarzowych — to zaś wynikało bezpośrednio z zakazu wystosowanego przez Episkopat Polski. Od 1971 r. duchowni włączyli się natomiast głównie we wspieranie budownictwa sakralnego ${ }^{80}$. Część księży $\mathrm{w}$ prywatnych rozmowach wyrażała zadowolenie $\mathrm{z}$ tego, że w grudniu nie użyto wojsk sowieckich, bo następstwem sowieckiej interwencji byłoby zaostrzenie kursu wobec Kościoła ${ }^{81}$. Zwracali oni jednak uwagę, że ,chuligańskie wybryki grudniowe spowodowane były przecież przez młodzież wychowaną w Polsce Ludowej. Przypomina się stwierdzenie Wł[adysława] Gomułki, «że od młodzieży zależy przyszłość Polski Ludowej, a taka ona będzie jaką wy ją zbudujecie». Otóż widzieliśmy to budownictwo w wypadkach grudniowych. Jeżeli w dalszym ciągu będziemy ateizować młodzież, a Kościołowi nie da się wolnej ręki w wychowaniu młodzieży, wówczas nastąpi krach moralny, którego próbki oglądaliśmy w ostatnim czasie" ${ }^{\wedge 2}$.

Należy przyznać, że z czasem sami hierarchowie zaczęli odchodzić od pewnych form otwartej krytyki władzy. Biskupi gdańscy i chełmińscy byli raczej zadowoleni z rezultatów rozmów przeprowadzanych z przewodniczącym Prezydium Wojewódzkiej Rady Narodowej - cieszyła ich nie tylko spokojna atmosfera tych rozmów, ale także deklarowana chęć normalizacji wzajemnych stosunków ze strony władzy i zauważalne tego efekty ${ }^{83}$.

Niezwykle trudno jest ocenić postawę duchownych na podstawie stosunkowo skąpych i fragmentarycznych informacji. Reakcja księży diecezjalnych i wygłaszane przez nich opinie są w dokumentach ledwie nadmienione, choć bez wątpienia stanowią swoiste świadectwo chwili. Przez wzgląd na specyfikę informacji zawartych w aktach SB nie da się w pełni odtworzyć stanowiska duchownych wobec władzy ${ }^{84}$ czy też ich rzeczywistej oceny wydarzeń

\footnotetext{
${ }^{78}$ AIPN Gd, 0046/350, t. XVI, Ocena sytuacji operacyjnej powiatu Starogard Gd. za okres 1965-1970, Starogard Gdański, 2 III 1971, k. 131.

${ }^{79}$ AAN, UdSW, 125/39, Aktualne problemy normalizacji stosunków pomiędzy państwem a Kościołem, k. 173.

${ }^{80}$ AIPN Gd, 0046/165, t. II, Ocena stanu zagrożenia bezpieczeństwa powiatu gdańskiego, Pruszcz Gdański, 8 II 1972, k. 7.

${ }^{81}$ AIPN Gd, 0046/350, t. XVII, Informacja dotycząca sytuacji ekonomiczno-politycznej, Kartuzy, 4 I 1971, k. 9.

${ }^{82}$ Ibidem, Informacja dot. postawy kleru w okresie wydarzeń grudniowych oraz zaistniałych zmian, k. 223-224.

${ }^{83}$ AIPN Gd, 299/34, Informacja na temat aktualnej sytuacji w Kościele rzymskokatolickim w województwie gdańskim, Gdańsk, 25 III 1971, k. 343.

${ }^{84} \mathrm{~W}$ odniesieniu do Szczecina również istnieje problem braku szczegółowych danych na temat zachowania tamtejszych księży. Zob. Z. Stanuch, op. cit., s. 61-67.
} 
grudniowych. Mogą to być zarówno opinie wyjątkowe (kapłan mógł na ten temat zabrać głos tylko raz, pod wpływem emocji), jak też wypowiedzi charakteryzujące określony i utrwalony pogląd. Jednak nawet odtworzenie tego poglądu oraz jego ewolucji nie mogłoby rzucić więcej światła na rzetelne postrzeganie postaw gdańskich duchownych. Nie pomogłoby też, jak można sądzić, w zrozumieniu powściągliwości ich zachowań. Wtłaczanie wszystkich w jeden schemat wygody bądź zwyczajnego strachu nie rozwiązuje problemu przy całej jego złożoności. Ciekawie na tym tle prezentuje się postawa pallotyna ks. Władysława Ciastonia, przeciwko któremu wszczęto postępowanie karne za rozpowszechnianie maszynopisów nawiązujących w swej treści do tragicznych wydarzeń na Wybrzeżu ${ }^{85}$.

$\mathrm{Z}$ powyższego zestawienia opinii duchownych wyłania się jednak pewien obraz. Kościół jest przez historiografię — i słusznie — postrzegany jako swoista enklawa wolności w PRL. Wielu księży zdawało się mieć tego pełną świadomość i starało się ze swojej strony bronić autonomii Kościoła, tak jak to było możliwe przy jednoczesnym nienarażaniu się władzy. Obrona autonomii oznaczała przecież obronę własnego status quo. Większość zwykłych księży zdawała się być zawieszona pomiędzy obowiązkami wynikającymi z pracy duszpasterskiej — przy wszystkich tego konsekwencjach — a poczuciem względnej stabilności.

Gdańska bezpieka odnotowywała często najbardziej jaskrawe przykłady przypominania o Grudniu 1970 przez duchownych województwa gdańskiego, niejednokrotnie w formie streszczenia czy omówienia, które - biorąc pod uwagę różny stopień przygotowania oficerów, często ignorancję, a czasem po prostu zwykły dyletantyzm — mogły (choć nie musiały) wypaczać sens danej wypowiedzi. Jest i kolejny aspekt. Funkcjonariusze Służby Bezpieczeństwa z natury nie odnotowywali wszystkich wypowiedzi kapłanów — uwaga ta dotyczy głównie postaw umiarkowanych bądź też zupełnie lojalnych wobec systemu. A większość duchownych po prostu nie zabierała głosu na temat Grudnia.

Przyczyna dość powściągliwej reakcji Kościoła katolickiego w Polsce na zajścia w grudniu 1970 r. leżała zapewne w polityce kardynała Stefana Wyszyńskiego. Sam prymas w Zapiskach więziennych kilka dni po aresztowaniu pod datą 27 IX 1953 r. tak wyjaśniał powody, dla których zdecydował się na pewne ustępstwa wobec komunistów: „Byłem od początku i jestem nadal tego zdania, że Polska, a z nią i Kościół święty, zbyt wiele utraciła krwi w czasie okupacji hitlerowskiej, by mogła sobie obecnie pozwolić na dalszy jej upływ. Trzeba za każdą cenę zatrzymać ten proces duchowego wykrwawiania się, by można było wrócić do normalnego życia, niezbędnego do rozwoju Narodu i Kościoła" ${ }^{86}$. Temu poglądowi, jak się wydaje, był wierny również w późniejszych latach. Eskalacja konfliktu jego zdaniem mogłaby się przyczynić do kolejnych tragedii. Prymas doskonale zdawał sobie sprawę z tego, że gdyby po Grudniu 1970 biskupi polscy nie podjęli widocznych działań zmierzających do poprawy relacji z władzą, szybko zostaliby oskarżeni o dążenie do ich zaostrzenia.

\footnotetext{
${ }^{85}$ AIPN Gd, 003/14, t. XVII, Informacja, 20 I 1971, k. 56.

${ }^{86}$ S. Wyszyński, Zapiski więzienne, Paryż 1982, s. 20. Wyjaśnienia prymasa odnosiły się do podpisanego w kwietniu 1950 r. porozumienia, które miało gwarantować polskiemu Kościołowi pewne swobody w zamian za ustępstwa stanowiące rodzaj legitymizacji władzy komunistów. Porozumienie to było krytykowane również przez Stolicę Apostolską. Zob. A. Dudek, Państwo i Kościót w Polsce 1945-1970, Kraków 1995, s. 22, 23.
} 


\section{The Attitude of the Clergy from Gdańsk Pomerania towards the December 1970 Events in the Light of Security Service Documents. An Attempted Characteristic}

The tragedy, which took place in 1970 in the streets of Gdańsk and Gdynia, became a prominent point of reference for relations between the state and the Catholic Church. Although at the time of the December events members of the clergy preserved a certain distance towards the incidents, they were interested in their course and became involved in appealing for the preservation of order. The calls aimed predominantly at avoiding an escalation of tension and protecting the health and lives of innocent people.

Prayers were said for the victims and the restoration of peace. Already in December 1970 the diocese of Gdańsk started to organise spiritual and material support for the families of the murdered and the wounded. At the beginning of the next year assistance assumed a more organised form and involved the bishops of Gdańsk - Edmund Nowicki and Lech Kaczmarek, as well as Bishop Kazimierz Kowalski of Chełmno. The power crisis simultaneously increased the growth of the influence enjoyed by the Church. The communist authorities indubitably tried to exploit the firm position of the Church for the purpose of legitimising their policy in the eyes of Polish society.

The Security Service embarked on a parallel intensification of its activity vis a vis the clergy, i.e. by observing assorted attitudes or recording opinions about the December events, expressed both in the course of Holy Mass and in private conversations. Views voiced by priests affected the attitude towards the communist authorities, while familiarity with such opinions served not merely a portrayal of the moods and tendencies prevailing among the clergy. The apparatus of repression was capable of stifling eventual symptoms of disapproval and a criticism of the system, e.g. by resorting to threats or warnings formulated in the course of talks.

One of the documents declares that younger clergymen approved the workers' protests in contrast to older priests, a feature distinctive for the December events.

The consequences of the alleviation of social moods included a normalisation of state-Church relations. The authorities regarded the course of talks held both at a central and a local level as vital. The bishops too tried to exploit such dialogues for resolving questions broached for years, such as the erection of churches or the restitution of Church property seized by the communists. 